\title{
Rate and extent of decline in Corallium (pink and red coral) populations: existing data meet the requirements for a CITES Appendix II listing
}

\author{
Andrew W. Bruckner ${ }^{1,2, *}$ \\ ${ }^{1}$ NOAA Fisheries, Office of Habitat Conservation, NOAA Coral Reef Conservation Program, 1315 East West Highway, \\ Silver Spring, Maryland 20910, USA \\ ${ }^{2}$ Khaled bin Sultan Living Oceans Foundation, 8181 Professional Place, Suite 215, Landover, Maryland 20785, USA
}

\begin{abstract}
In June 2007, the US government proposed Corallium (pink and red corals) for listing on Appendix II of the Convention on International Trade in Endangered Species (CITES). The proposal was adopted and later overturned due to perceived difficulties in implementing and enforcing a CITES listing and uncertainties on population status. An expert review (Food and Agriculture Organization) questioned whether populations had declined to $20-30 \%$ of the historic baseline, the level required for a CITES Appendix II listing. This review used colony abundance and density as surrogates of decline, which may be high (200 to 1300 colonies $\mathrm{m}^{-2}$ ) in the Mediterranean. Yet assessments of decline for colonial organisms should also consider changes in size, since reproductive output and survival increase exponentially with size. Colonies of C. rubrum historically achieved heights of $50 \mathrm{~cm}$ with complex first, second and third order branching patterns. Today, $>90 \%$ of colonies in fished areas are 3 to $5 \mathrm{~cm}$ tall, $<50 \%$ are sexually mature and most have only rudimentary branches. Few population data are available for Pacific Corallium spp.; however, landings over the last $15 \mathrm{yr}$ have declined from 100-400 to $<5 \mathrm{t} \mathrm{yr}^{-1}$. Recovery of populations to their natural state may require decades, as colonies in protected areas are less than half their historic size after 20 to $30 \mathrm{yr}$ of protection. Minimum allowable size for harvest should be increased because traditionally determined growth rates appear to underestimate colony age, and corals are being removed long before achieving maximum sustainable yield. 'Boom and bust' cycles of Corallium fisheries and dramatic, long-lasting shifts in population demography highlight the need for improved management and trade regulations.
\end{abstract}

KEY WORDS: Precious coral · Pink and red corals · Corallium $\cdot$ Harvest $\cdot$ Trade $\cdot$ Coral jewelry

\section{INTRODUCTION}

Precious corals have been highly valued since ancient times for use in the fabrication of jewelry, amulets and art objects (Tescione 1973). Precious corals is a collective term referring to gold corals (Gerardia spp.) in the order Zoanthidae, black corals in the order Antipatharia and 2 groups in the order Gorgonacea: bamboo corals (Acanella and Lepidisis spp.) and pink and red corals (Corallium and Paracorallium spp.). Pink and red corals are the most valuable precious corals in commerce and among the rarest (Grigg 1989). For instance, the US Hawaiian precious coral industry generated about US\$2 million in 1969, with increases to US $\$ 15$ million in 2001 and US $\$ 70$ million in 2006 (Grigg 1993, 2001, 2006). There are currently about 300 pink and red coral producers in the Torro del Grecco area of Italy, the global center of Corallium artifact production, with annual revenues of about US \$200 million (Mauro Ascione pers. comm.).

The history of precious coral exploitation began in the Mediterranean with the red coral Corallium rubrum, which has been found with 25000 yr old Paleolithic human remains (Tescione 1965). During ancient times, most red coral was collected after heavy storms broke off branches and washed them up on shore. Har- 
vest of living colonies of Corallium started about 5000 yr ago with Greek fishermen using kouralio or iron hooks to dislodge colonies from deeper water, and by Greek sponge divers capable of free diving to over $80 \mathrm{~m}$ depth (Mayol 2000). Precious coral fisheries expanded around $1000 \mathrm{AD}$ with the development of the ingegno or St. Andrews Cross, a wooden cross with attached nets that was dragged across the bottom to entangle coral (Tescione 1973). The modified 'barra italiana,' a coral dredge consisting of an iron bar ( $>1 \mathrm{t})$ with chains and nets attached along its length, has been widely used since the 1830s off Italy (Grigg 1984). Using the new dredge, the fishery increased from 347 boats in 1862 to 1200 vessels and 24 Italian factories processing coral, employing about 17000 fishermen and jewelers by 1865 (Tescione 1965, 1973). Further growth of the fishery ( $>2000$ boats) followed the discovery of large coral beds between Sicily (Italy) and Tunis (Tunisia) in the 1880s, with continued expansion to other Mediterranean countries during the 1900s (Tescione 1965). The selective removal of C. rubrum using SCUBA diving emerged as a viable alternative in the 1950s, and by the mid-1980s most red coral was harvested using SCUBA. This change was largely due to a ban on the use of coral dredges, but divers also demonstrated the ability to obtain yields that were comparable to dredge fisheries through harvest from crevices, overhangs and other locations that were previously inaccessible to dredges (Tsounis 2005). Coral divers in France, Italy and Spain typically descend to depths of 30 to $100 \mathrm{~m}$ on air, but depletion of shallow resources is forcing more divers into deeper water (to $140 \mathrm{~m}$ ) using mixed gases (Chessa \& Cudoni 1988, Galasso 2000, Santangelo et al. 1993, Tsounis et al. 2006a, Rossi et al. 2008).

Commercially viable beds of Corallium were first discovered in the Pacific off Japan in the early 1800s, but the fishery didn't flourish until after the Meiji Reform in 1868 (Kosuge 1993). Over the next century, most Pacific landings were from mid-depth beds (100 to $400 \mathrm{~m}$ depth) off Japan (Okinawa and the Bonin Islands) and China (Taiwan) (Grigg 1977). In 1965, following the discovery of a large bed of $C$. secundum, Corallium fisheries shifted to the Milwaukee Banks in the Emperor Seamount Chain. Landings from the Milwaukee Banks reached about $150 \mathrm{t}$ in 1969 and then rapidly dropped off until the discovery of a previously undescribed species (Midway deep-sea coral, Corallium sp. nov.) in deep water (900 to $1500 \mathrm{~m}$ ). This discovery led to another short-lived 'coral rush', with peak production of about $300 \mathrm{t}$ in 1981. After a period of inactivity, largely due to market saturation, fishing resumed and landings reached a historic high of $400 \mathrm{t}$ in 1988 (Grigg 1993). By 1991, these beds were exhausted and landings dropped by over $90 \%$, with only 3 t recorded Pacific wide. Less than 10 thave been harvested annually over the last $15 \mathrm{yr}$, mostly from the far western Pacific (FAO 2008).

Due to environmental concerns associated with $\mathrm{Co}$ rallium fisheries, SeaWeb (a non-governmental organization) petitioned the USA to propose Corallium for listing on the Appendices of the Convention on International Trade in Endangered Species (CITES) in 2006. Because of the high value of Corallium, these resources have been intensely fished in both the Pacific and Mediterranean, with a well-established pattern of discovery, exploitation and depletion (Grigg 1989). In addition to localized depletions, the use of coral dredges has damaged Corallium habitats, disrupting the critical role these species play as nursery, feeding and refuge areas for fishes and motile invertebrates (Chessa \& Cudoni 1988). Throughout most of the Mediterranean, the complex, 3dimensional 'forest-like' structure has been transformed to low-relief 'grass plain-like' habitats (García-Rodríguez \& Massó 1986).

After a detailed review and consultation with countries known to have populations of Corallium in their territorial waters, the USA submitted a proposal at the 13th Conference of the Parties in June 2007 to list all species of Corallium (pink and red corals) in Appendix II of CITES (Anonymous 2007). This proposal identified 7 species of Corallium as under considerable threat from harvest and international trade, with other species recommended for listing because of their similarity in appearance to other regulated species (Wijnstekers 1988). The US proposal for listing Corallium in CITES Appendix II was adopted and later overturned largely due to perceived challenges in implementing and enforcing this CITES listing, and the conclusion that insufficient data was available on the population status to warrant a listing (Morell 2007). According to an expert FAO review, these species had not declined to $20-30 \%$ of the historic baseline, as required for listing a low productivity species on CITES Appendix II (FAO 2007).

The conclusion that Corallium populations had not undergone a substantial decline, as presented by FAO (2007), was based on available data on colony abundance and density as an indicator of population status. Both measures may be relatively high (200 to 1300 colonies $\mathrm{m}^{-2}$ ) in the shallow coralligenous zones of the Mediterranean (Garrabou \& Harmelin 2002, Santangelo et al. 2004, Tsounis et al. 2006a), yet changes in abundance are likely to be inadequate measures of decline for colonial (modular) organisms such as Corallium, as they exhibit a size-based exponential increase in reproductive output. Therefore, their continued survival is dependent on both colony size and density to ensure successful reproduction and fertilization (Tsounis et al. 2006b). Furthermore, recent findings on biol- 
ogy, genetics and population dynamics (Abbiati et al.1992, Marschal et al. 2004, Roark et al. 2006, Rossi et al. 2008), as well as increased reports of illegal fishing (Tsounis et al. 2006a, Rossi \& Gili 2007), highlight the increased vulnerability of these taxa to fishing and the inadequacy of existing management. The present review was undertaken to better understand the effects of harvest on Corallium populations and the validity of CITES as a conservation tool for these taxa. Available data on fisheries landings, international trade and population demography (including changes in abundance, density and size structure) are used to estimate Corallium decline. The implications of a shift of the size/age structure on reproduction and recruitment, and how these changes may affect the future persistence of Corallium, are presented. Existing and proposed management actions and possible international regulations through a CITES listing are also examined in the context of new population and biological data, benefits of these actions to protect and rebuild exploited populations of Corallium and possible limitations of a CITES listing from both a conservation and administrative standpoint.

\section{MATERIALS AND METHODS}

Taxonomy. Corallium spp. (Order Gorgonacea [Alcyonacea], family Coralliidae, subdivided into 2 genera, Corallium and Paracorallium; Bayer \& Cairns 2003) includes 31 described species of pink and red corals, of which 8 are used for jewelry. Six species are reported in FAO landings data (Table 1), and 2 additional commercially valuable species $(C$. regale and $C$. lauuense) are listed in the US Fishery Management Plan for the Precious Coral Fisheries (US Dept of Commerce 1980), although these 2 species may be synonymous. Throughout this paper the generic name Corallium is used to refer to both genera. Corallium is found at low densities throughout most tropical, subtropical and temperate oceans (Fig. 1). Populations of commercial interest occur only in areas north of latitude $19^{\circ} \mathrm{N}$. In the Pacific, exploitable coral beds occur from Japan to the northern Philippines (19 to $36^{\circ} \mathrm{N}$ ) and from the Hawaiian Islands $\left(20^{\circ} \mathrm{N}\right)$ to Milwaukee Banks (Grigg 1974) at 2 depth ranges (90 to $575 \mathrm{~m}$ and 1000 to 1500 m) (Grigg 1974, Baco \& Shank 2005). In the Mediterranean, C. rubrum occurs primarily around the central and western basin ( 7 to $300 \mathrm{~m}$ depth) with smaller populations in deeper water (60 to $200 \mathrm{~m}$ ) in the eastern basin and off the Atlantic coast of Africa (Table 1).

Data sources. FAO Official Fishery Statistics (FAO 2008) provided annual data on precious coral landings for the Pacific and Mediterranean for the last $45 \mathrm{yr}$. Japan and China (Taiwan) submitted data for 5 Pacific species (Corallium japonicum, C. konojoi, C. secundum, C. elatius and Corallium sp. nov.), and 12 countries in the Mediterranean report C. rubrum landings (Fig. 2). The US Fish and Wildlife Service, Division of Law Enforcement, compiles import data for Corallium subdivided for each species by the number of pieces or total weight with limited information on product type (live animal, skeleton, jewelry or art object).

Estimation of decline. Relationships between colony size and reproductive output were examined as a measure of colony fitness based on population demographics for Corallium rubrum in Spain (García-Rodríguez \& Massó 1986a,b, Tsounis et al. 2006a,b, Rossi et al. 2008), Italy (Abbiati et al. 1993, Santangelo et al. 2003, 2007) and France (Garrabou \& Harmelin 2002). Available demographic data (population density and colony height, diameter and age) were used to develop size-frequency distributions for 5 different populations: (1) a shallow coastal population off Calafuria, Italy (Santangelo et al. 2003), dominated by small, short-lived colonies with $<1 \%$ reaching the minimum legal size for harvest (7 mm diameter) prior to mortality; (2) shallow fished areas off Costa Brava, Spain (Tsounis et al. 2006a,b); (3) a protected area off Medas Island, Spain (Tsounis 2005); (4) deep populations in areas with low fishing

Table 1. Corallium spp. Predominant species targeted by fisheries and their known distributions. FAO official landings data (FAO 2008) in metric tons (t) were pooled for 1968 to 2006 and depth, except for C. lauuense which represents landings in Hawaii during a single year (Grigg 1993)

\begin{tabular}{|c|c|c|c|c|}
\hline Taxa & Common name & Distribution & $\begin{array}{l}\text { Depth } \\
\text { (m) }\end{array}$ & $\begin{array}{l}\text { Reported } \\
\text { landings }(\mathrm{t})\end{array}$ \\
\hline C. japonicum & Aka-sango, Moro & Japan, Okinawa, Bonin Islands south to $26^{\circ} \mathrm{N}$ & $100-300$ & 62 \\
\hline C. konojoi & Shiro-sango & Japan to northern Philippines $\left(26-36^{\circ} \mathrm{N}\right)$ & $50-200$ & 3 \\
\hline C. secundum & Angel skin, Pelle d' ange & Hawaii to Milwaukee Banks $\left(20-36^{\circ} \mathrm{N}\right)$ & $230-575$ & 1890 \\
\hline C. elatius & Momo, Momoiro-sango, Misu & Japan to northern Philippines $\left(26-36^{\circ} \mathrm{N}\right)$ & $150-400$ & 160 \\
\hline Corallium sp. nov. & Midway deep-sea coral & Midway Island to Emperor Seamount $\left(28-36^{\circ} \mathrm{N}\right)$ & $1000-1500$ & 772 \\
\hline C. rubrum & Red coral, Noble coral & Mediterranean, East Atlantic off Africa & $10-250$ & 1259 \\
\hline $\begin{array}{r}\text { C. lauuense } \\
\text { (C. regale) }\end{array}$ & Pink coral & Hawaii $\left(20-28^{\circ} \mathrm{N}\right)$ & $390-500$ & 0.062 \\
\hline
\end{tabular}



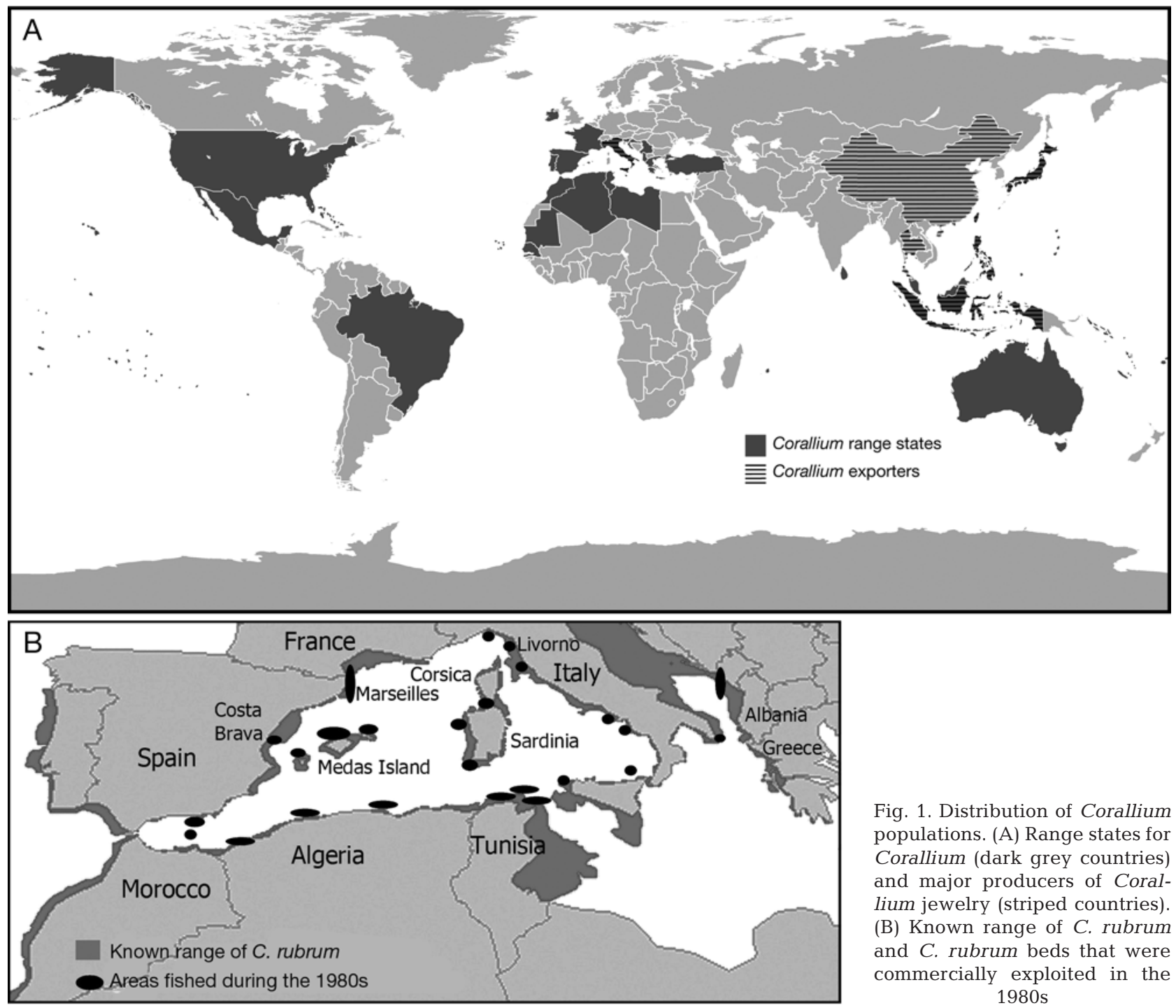

Fig. 1. Distribution of Corallium populations. (A) Range states for Corallium (dark grey countries) and major producers of Corallium jewelry (striped countries). (B) Known range of C. rubrum and $C$. rubrum beds that were commercially exploited in the 1980s

pressure (Rossi et al. 2008); and (5) historic populations from 30 to 40 yr ago (García-Rodríguez \& Massó 1986a,b, Garrabou \& Harmelin 2002).

Total larval production per unit area was calculated for each of the 5 populations using published data on size/age at first reproduction, mean number of planula per fertile polyp and total number of planula produced annually per colony, estimated from the height of individual colonies and total number of branches. For simplification, several basic assumptions were made: (1) a 1:1 sex ratio (Tsounis et al. 2006b); (2) each mature polyp produces 0.87 planula per year with no differences between different branch segments (e.g. branch tip versus branch middle; first and second order branches) (Santangelo et al. 2003), or with size of the colony; (3) a mean of 4 polyps $\mathrm{mm}^{-1}$ (Bramanti et al. 2005) regardless of colony diameter; and (4) planula mortality rates of $95 \%$ before settlement (Santangelo et al. 2004). Estimates of the total annual production for each population and number of planula recruiting annually into these populations were then calculated based on an assumption that they are self-seeding, using a relative area of coverage. This is mainly because density estimates were not available for most locations, and when available, these varied depending on the sampling strategy: some studies presented density within a small patch, which may be locally high, while others estimated density for an entire zone or depth, which is significantly lower. Reproductive parameters have been previously evaluated in coastal populations dominated by small colonies (colonies up to $15 \mathrm{yr}$ old, <10 cm height, $7 \mathrm{~mm}$ diameter), with diameter and estimated age used to illustrate size-based increases in reproductive output (Santangelo et al. 2003; see my Table 3). Because this method underestimates total reproductive output for larger colonies that 

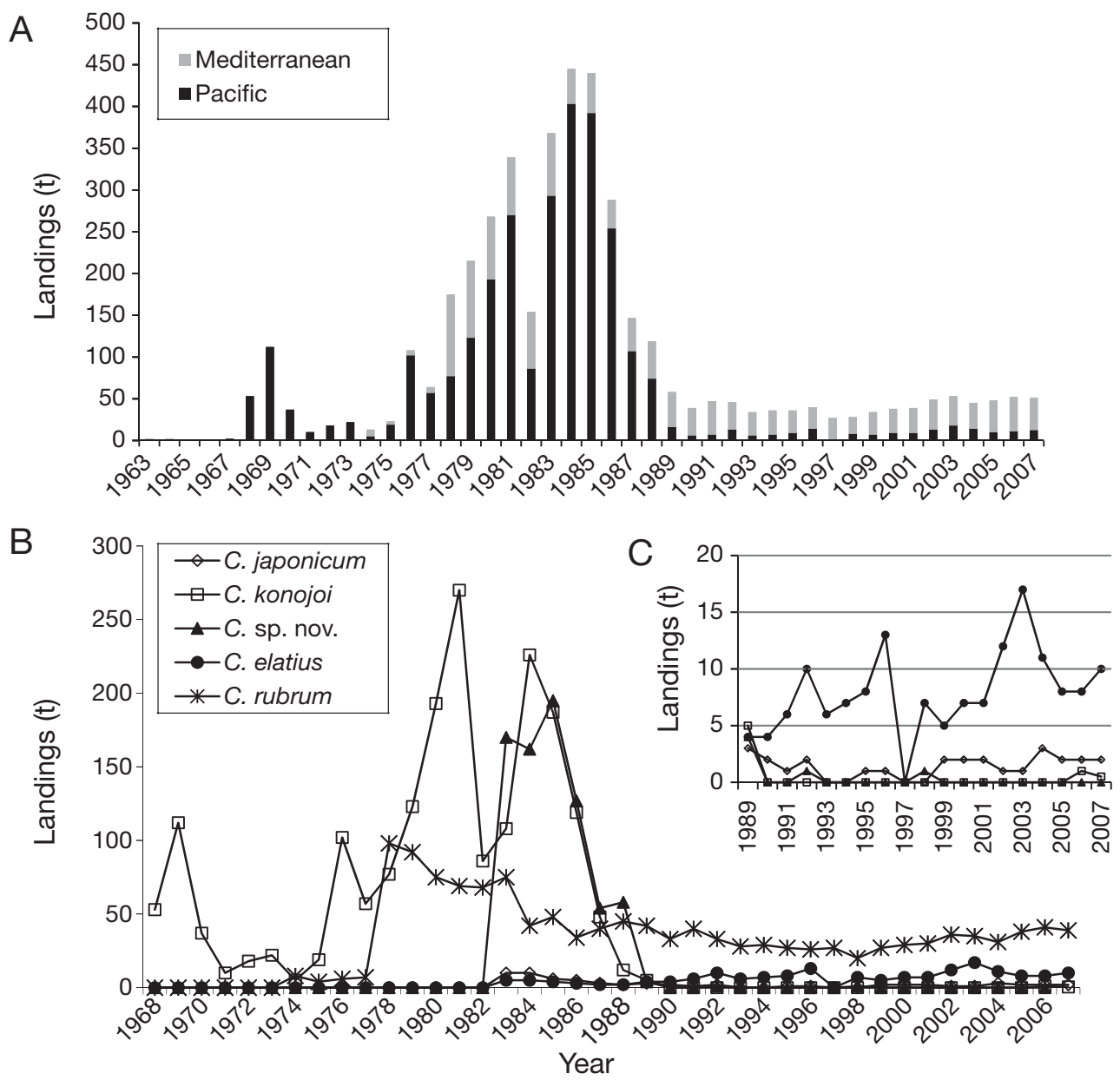

Fig. 2. Corallium spp. FAO landings data (A) Total landings for the Pacific and Mediterranean from 1963 to 2007 . (B) Reported landings for 4 major Pacific species (C. japonicum, C. konojoi, C. elatius, C. sp. nov.) and 1 Mediterranean species (C. rubrum) from 1968 to 2007. (C) Reported landings from 1989 to 2007 for the 4 Pacific taxa listed in (B)

develop multiple first, second, third and fourth order branches, photographic images of Corallium rubrum of different sizes were analyzed to determine the total number of branches and cumulative branch length for different-sized colonies. Furthermore, data from different locations were not directly comparable for the following reasons: (1) some researchers have inferred relationships between age and colony diameter from growth rings, while others have used actual measurements of growth; (2) height and diameter are not necessarily directly correlated, as interhabitat differences (e.g. exposure, currents, depth) affect growth rates and colony morphology (Tsounis 2005); and (3) size frequency distribution varies between studies depending on the methodology used. In some cases the size structure was determined by scraping all colonies from within a quadrat, which provides data on recruits and adults, while other studies (e.g. historic populations) are based on museum collections and fisheries landings which only include larger colonies.

\section{RESULTS \\ Landings}

\section{Pacific Ocean}

Landings of Corallium from the Pacific reported by Japan and China (Taiwan) show 5 major peaks over the 45 yr for which data have been compiled (Fig. 2). Taiwan's reported landings were 2 to 3 times greater than that reported by Japan with 4 major peaks in landings of C. secundum in 1969 (112 t), 1976 (102 t), 1981 (270 t) and 1984 (226 t), with Midway coral Corallium sp. nov. accounting for over $90 \%$ of the world's production from 1983 to 1986 (564 t). Landings by Taiwan remained at low levels $(<5 \mathrm{t})$ over the next $20 \mathrm{yr}$ with the exception of 2 small peaks in 1996 (12 t) and 2002-2004 (35 t) of C. elatius from mid-depth coral beds between Taiwan and the Philippines (Fig. 2B). Annual yield from Japan was the greatest from 1979 to 
1984 (57 to $91 \mathrm{t} \mathrm{yr}^{-1}$ ), with 70 to $90 \%$ consisting of Midway coral. Reported landings declined to $2.6 \mathrm{t}$ in 1987 and have remained at $<5 \mathrm{t} \mathrm{yr}^{-1}$ over the last $20 \mathrm{yr}$, consisting mostly of $C$. elatius (mean $=1.9 \mathrm{t} \mathrm{yr}^{-1}$ ) and $C$. japonicum (1.2 $\left.\mathrm{t} \mathrm{yr}^{-1}\right)$ with lower amounts of $C$. konojoi and Corallium sp. nov. (0.22 $\mathrm{t} \mathrm{yr}^{-1}$ ) (Fig. 2B). A small fishery was also active in US waters off Oahu, Hawaii (Makapuu Bed), from 1966 to 1978 with $1.8 \mathrm{t}$ of $C$. secundum landed from 1966 to 1969 using a dredge and 6.4 t from 1973 to 1978 using a submersible.
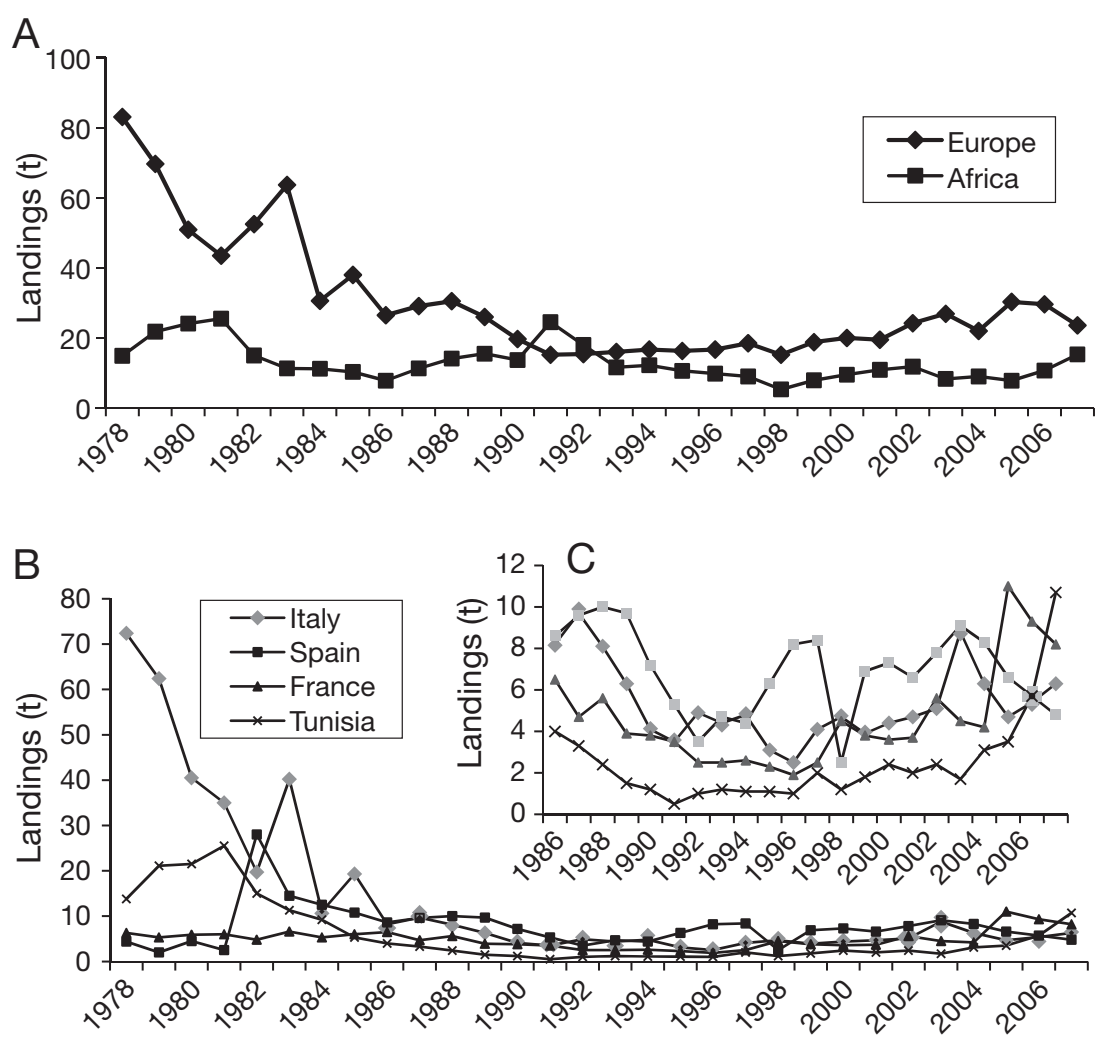

D

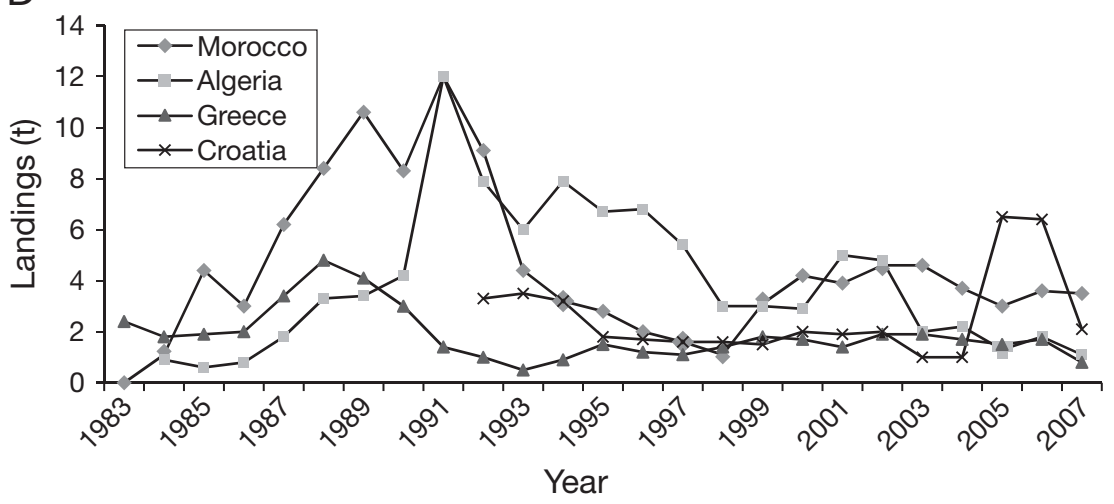

Fig. 3. Corallium rubrum. (A) Landings reported by European and African countries from 1978 to 2007. (B) Landings for the 4 largest sources of $C$. rubrum: Italy, Spain, France and Tunisia. (C) Landings for (B) over the last $20 \mathrm{yr}$; note the different $y$-axis scale. (D) Landings for Morocco, Algeria, Greece and Croatia

\section{Mediterranean Sea}

The total yield of Corallium rubrum reported over a 30 yr period (1976 to 2006) was 1250 t, with $33.5 \%$ from Italy, $17.6 \%$ from Spain, $15.3 \%$ from Tunisia and $9.9 \%$ from France. Landings from these 4 major source countries show a decreasing trend over $15 \mathrm{yr}$ (>85\% decline from $97 \mathrm{t}$ in 1976 to $12 \mathrm{t}$ in 1992), mostly due to reduced yields from European countries, especially Italy (70 t in 1978 versus $8 \mathrm{t}$ in 1986; Fig. 3B). Total annual yield for these 4 countries fluctuated between 12 and $18 \mathrm{t}$ from 1992 to 2003 with progressive increases to $26 \mathrm{t}$ by 2006 . Annual landings from all African countries (pooled) show irregular fluctuations from 5 to $30 \mathrm{t}$ with Tunisia reporting a total of $68 \mathrm{t}$ over $4 \mathrm{yr}$ (1979 to 1982), and Morocco and Algeria reporting about $88 \mathrm{t}$ between 1988 and 1992 (Fig. 3A,C). Total production for Albania, Croatia, Greece, Montenegro, Turkey and Yugoslavia has been $<5 \mathrm{t} \mathrm{yr}^{-1}$ with the exception of a short-lived increase in landings off Greece (1987 to 1990) and Croatia (1992 to 1994). The Croatian fishery experienced a sharp fall in landings after 1994 and then increased sharply in 2005 and 2006. A limited amount of red coral was landed in waters off Yugoslavia and Turkey in the early 1990s, while Montenegro provided landings data for the first time in 2006.

\section{USA imports}

China (including Hong Kong and Taiwan), Japan and Italy are currently the largest manufacturers of Corallium jewelry with most imports destined for the USA. Other important exporting countries include India, Indonesia, Korea, Thailand and the Philippines, although the origin of the raw material is primarily from the Mediterranean, Taiwan or Japan. From 2001 to 2008, the USA imported over 28 million pieces of Corallium jewelry and $80 \mathrm{t}$ of skeletons. Imports were lowest during 2001 to 2002, increased significantly from 2003 to 2005 and then dropped 

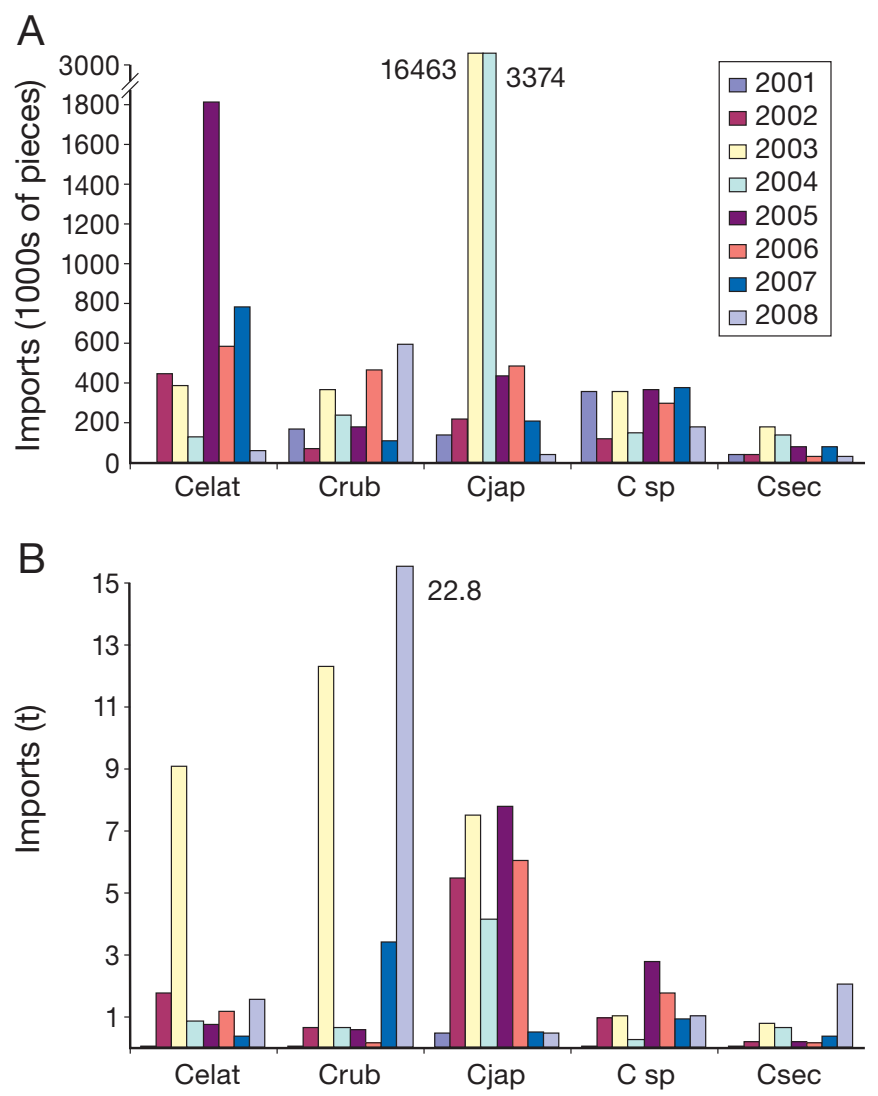

Fig. 4. Corallium spp. Imports of 5 species into the US between 2001 and 2008. Celat: C. elatius; Crub: C. rubrum; Cjap: C. japonicum; C sp: Corallium sp. nov.; Csec: C. secundum. Total imports of (A) manufactured Corallium (reported by piece) and (B) unprocessed Corallium skeletons (metric tons) off in 2006, with notable increases in C. rubrum in 2007 and 2008 (Fig. 4). The taxa listed as being traded at highest volume is $C$. japonicum, representing $>75 \%$ of all manufactured items and $45 \%$ of the raw skeletons imported over the last 7 yr. Interestingly, C. japonicum is extremely rare due to past overharvesting, and these records may represent jewelry manufactured from stockpiled resources, or a misidentification. A high volume of $C$. elatius skeletons was also imported in 2003 (>9 t) and a large amount of $C$. elatius jewelry was imported in 2005 (>1.8 million pieces). There were also 2 major peaks in imports of unprocessed skeletons of C. rubrum in $2003(12.3 \mathrm{t})$ and $2008(22.8 \mathrm{t})_{i}<5 \%$ of skeletons consist of this taxa during other years, while processed C. rubrum jewelry increased sharply in 2006 and 2008 (Fig. 4).

\section{Abundance and density}

Corallium abundance and patchiness varied between species and across the geographic distribution and depth range of individual species. The 3 largest known Corallium beds off Hawaii exhibited low densities and overall low total numbers of colonies with all beds relatively small in size. The largest bed, Makapuu Bed off Oahu, Hawaii $\left(4.3 \mathrm{~km}^{2}\right)$, supports $C$. secundum at a density of 0.3 colonies $\mathrm{m}^{-2}$ with a total population size estimated at 120000 colonies in 2001 (Grigg 2002). The total number of colonies in all other characterized beds in the US is also low, including an estimated 2500 legal-sized colonies of $C$. regale at

Table 2. Corallium rubrum. Population structure off Spain, France and Italy. Diameter and height are presented as mean \pm SD (maximum) if reported

\begin{tabular}{|c|c|c|c|c|c|c|}
\hline Location & $\begin{array}{l}\text { Depth } \\
(\mathrm{m})\end{array}$ & $\begin{array}{l}\text { Growth rate } \\
\left(\mathrm{mm} \mathrm{yr}^{-1}\right)\end{array}$ & $\begin{array}{l}\text { Basal diameter } \\
\qquad(\mathrm{mm})\end{array}$ & $\begin{array}{l}\text { Height } \\
(\mathrm{mm})\end{array}$ & $\begin{array}{l}\text { Density } \\
\text { (ind. } \mathrm{m}^{-2} \text { ) }\end{array}$ & Source \\
\hline \multicolumn{7}{|l|}{ Spain } \\
\hline \multirow[t]{5}{*}{ Costa Brava } & & 1.32 & 7.2 & 61.8 & & García-Rodríguez \& Massò (1986a,b) \\
\hline & $10-25$ & & $4.8 \pm 2.1$ & $27 \pm 17.1$ & 130 & Tsounis (2005), Tsounis et al. $(2007 a, b)$ \\
\hline & $25-60$ & & & 40 & & Tsounis (2005), Tsounis et al. $(2007 a, b)$ \\
\hline & $60-120$ & & & 60 & 43 & Rossi et al. (2008) \\
\hline & $>120$ & & & 80 & $<1$ & Rossi et al. (2008) \\
\hline Medas Island & $15-48$ & & $6.9 \pm 2.4$ & $41.9 \pm 25.6$ & 130 & Tsounis (2005), Tsounis et al. $(2007 a, b)$ \\
\hline Historic (1962) & $25-35$ & & $16 \pm 0.4(45)$ & $114.5 \pm 25(155)$ & & $\begin{array}{l}\text { Garrabou et al. (2001), Garrabou \& } \\
\text { Harmelin (2002) }\end{array}$ \\
\hline \multicolumn{7}{|r|}{ 1 } \\
\hline Marseilles Harvested & $23-50$ & 0.24 & $6.4 \pm 0.5(11)$ & $69.3 \pm 12(130)$ & $400-600$ & $\begin{array}{l}\text { Garrabou et al. (2001), Garrabou \& } \\
\text { Harmelin (2002) }\end{array}$ \\
\hline Marseilles Reserve & 23 & & $11.6 \pm 0.3(19)$ & $118.1 \pm 19(170)$ & & $\begin{array}{l}\text { Garrabou et al. (2001), Garrabou \& } \\
\text { Harmelin (2002) }\end{array}$ \\
\hline \multicolumn{7}{|r|}{ 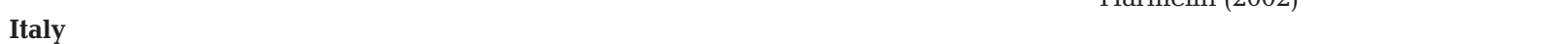 } \\
\hline Calafurio & $25-35$ & 0.91 & 3.9 & 40 & 1300 & Santangelo et al. $(1993,2003,2004)$ \\
\hline
\end{tabular}


Cross Seamount and up to 7000 legal-sized colonies at Keahole Point Bed.

The density and abundance of Corallium rubrum colonies shows an inverse relationship with depth. Densities can be locally high at depths of 10 to $50 \mathrm{~m}$ (130 to 5200 colonies $\mathrm{m}^{-2}$; Table 2), with corals consisting primarily of recruits (>50\%) and small (2 to $5 \mathrm{~cm}$ tall) adult colonies. In Spain, shallow (15 to $50 \mathrm{~m}$ depth) C. rubrum populations are confined to small patches within specific habitats (mean $=2.5$ patches $100 \mathrm{~m}^{-1}$ ), often at high densities (mean $=130$ colonies $\mathrm{m}^{-2}$ ), but overall density for the entire coralligenous zone within this depth range is estimated at 3.4 colonies $\mathrm{m}^{-2}$. Patches of $C$. rubrum are more common at mid-depths $\left(50\right.$ to $90 \mathrm{~m}$ depth, mean $=8.3$ patches $\left.100 \mathrm{~m}^{-1}\right)$, while mean densities are lower (43 colonies $\mathrm{m}^{-2}$ ). Below $120 \mathrm{~m}$ depth, colonies occur at very low densities.

\section{Size structure}

Significant differences in the size of Corallium rubrum colonies were reported between locations and depths, and most areas exhibited a general trend of declining size structure over the last 4 decades (Table 2). Colonies collected in the 1950s and 1960s were frequently up to $50 \mathrm{~cm}$ in height and $2 \mathrm{~cm}$ in diameter. A 1962 collection off Costa Brava, Spain, consisted of colonies with basal diameters of 10 to 45 $\mathrm{mm}($ mean $=16 \mathrm{~mm})$ and heights of 10 to $50 \mathrm{~cm}$ $($ mean $=11.5 \mathrm{~cm})$ with the largest corals estimated at 50 to 80 yr old. Colonies sampled off Costa Brava were still substantially larger in 1986 than that observed today, with $85 \%$ of the colonies having a basal diameter $>5 \mathrm{~mm}$. Shallow populations from Costa Brava (10 to $25 \mathrm{~m}$ depth) are now skewed towards small corals (mean height $=3.1 \mathrm{~cm}$, max. height $=20 \mathrm{~cm}$; mean diameter $=4$ to $5 \mathrm{~mm}$ ), most of which are young (<8 yr old) and only $35 \%$ have basal diameters $>5 \mathrm{~mm}$. Surveys from 2002 also showed an increase in colony height with depth to $4 \mathrm{~cm}$ height at 25 to $50 \mathrm{~m}$, and $6 \mathrm{~cm}$ at 50 to $90 \mathrm{~m}$; the largest colonies (13 to $16 \mathrm{~cm}$ height) were found in non-harvested areas below $50 \mathrm{~m}$ depth. Colonies in an adjacent protected area (Medas Island, Spain) closed to fishing for $15 \mathrm{yr}$ were 20 to $50 \%$ larger (mean height $=4 \mathrm{~cm}$, max. $=20 \mathrm{~cm}$ ) than colonies at similar depths in fished areas off Costa Brava. Populations examined in 1998 in fished areas off France (Marseilles) were larger (mean height $=6 \mathrm{~cm}$; range $=4$ to $13 \mathrm{~cm}$ ) than those reported for Spain (although small colonies were not examined in Marseilles). These colonies were also only about half the size of a similar habitat in France protected from fishing since 1983 (mean = $11.8 \mathrm{~cm}$, range $=8$ to $17 \mathrm{~cm}$; Table 2).

\section{Effects of size and age on reproduction}

The 5 populations examined exhibited significant differences in total reproductive output that was directly related to colony size structure and the degree of branching (Fig. 5). Corallium rubrum are gonochoric brooders that were reported to first produce gonads at 2 to $10 \mathrm{yr}$ of age (minimum height $=2$ to $3 \mathrm{~cm}$, diameter $=1.8$ to $3.6 \mathrm{~mm}$ ), with colonies achieving $100 \%$ fertility at 4 to $6 \mathrm{~cm}$ in height. The total number of polyps
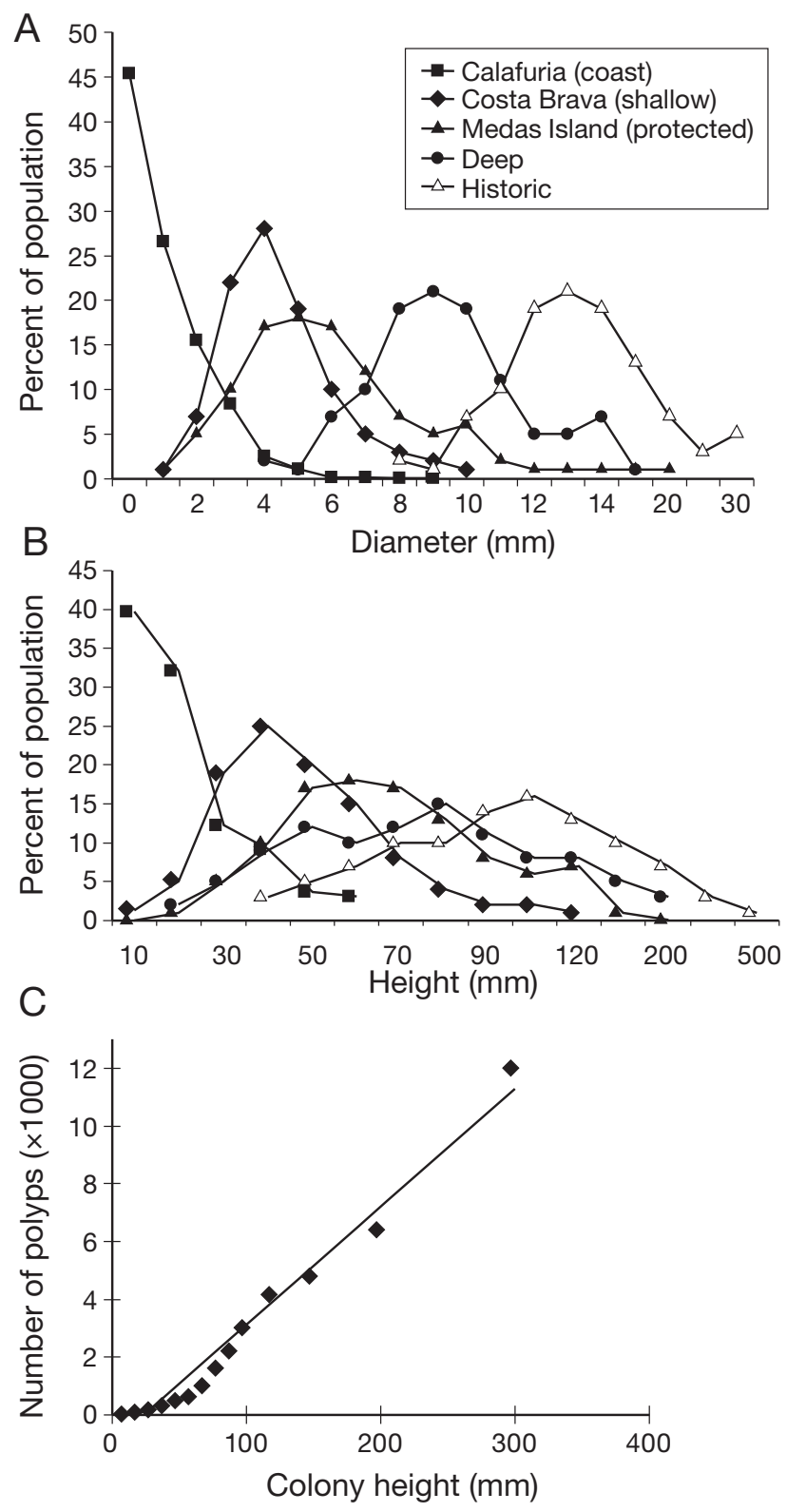

Fig. 5. Corallium rubrum. Estimated size structure of 5 types of populations in the Mediterranean. Frequency distributions of (A) diameter and (B) height, and (C) relationship between number of polyps and colony height. Note non-linear $X$-axis scale in (B) 
increased exponentially with colony size from about 90 polyps in a small $(2 \mathrm{~cm}$ height), single-branched colony, to $>4000$ in a $12 \mathrm{~cm}$ tall colony with over 35 branches and 15000 for colonies $30 \mathrm{~cm}$ in height (Fig. 5C). The Califuria (Liverno, Italy) population (25 to $35 \mathrm{~m}$ ) was characterized by a decreasing monotonic demographic pattern dominated by young colonies (two-thirds are pre-reproductive) with only 1 or 2 branches, and $<1 \%$ reaching legal minimum size of harvest before mortality. Colonies began reproducing at an early age $(2 \mathrm{yr})$ and released 0 to 158 planulae each per year ( 350 total over the 6 yr lifespan). Most reproductive output of this population (14325 planula per unit area; 700 survive to settlement) was produced by the smaller size classes (1.9 to $4.3 \mathrm{~mm}$ diameter). Shallow populations off Costa Brava, Spain (10 to $50 \mathrm{~m}$ depth), were also dominated by small colonies (mean height $=3 \mathrm{~cm})$; most $(96 \%)$ have 1 branch, and only 7 to $16 \%$ of the colonies were $>6 \mathrm{~cm}$ in height. Gametes were found in colonies as small as $2 \mathrm{~cm}$ in height; $60 \%$ of polyps in colonies 2 to $4 \mathrm{~cm}$ were fertile, while colonies of 4 to $6 \mathrm{~cm}$ in height were $100 \%$ fertile. These populations produced approximately 4 times as many planulae as the Liverno population, with the highest proportion of larvae produced by colonies 8 to $10 \mathrm{~cm}$ in height, even though these made up about $10 \%$ of the population. Medas Island (protected area) populations were slightly larger in size (mean height $=4 \mathrm{~cm}$ ) than shallow Costa Brava fished populations. These are capable of producing about twice as many planulae with most production by colonies over $6 \mathrm{~cm}$ in height. Deep $(50$ to $90 \mathrm{~m}$ ) populations with low fishing pressure consisted of larger colonies (mean height $=4$ to $6 \mathrm{~cm}$ ) with more complex branching patterns and a total larval production that was 3 times higher than the shallow fished areas. Historic populations (1962) contained colonies with a mean size approximately 3 times larger than that observed today (mean height $=11 \mathrm{~cm}$ ), including many highly branched colonies up to $50 \mathrm{~cm}$ tall. These populations are estimated to have produced up to 300000 planulae per unit area, with colonies from 10 to $20 \mathrm{~cm}$ in height ( $46 \%$ of the population) producing $>65 \%$ of the planulae (Table 3 ).

\section{DISCUSSION}

Corallium has been intensively exploited for centuries, and both landings and population data provide strong evidence that most commercially viable Corallium beds are now depleted. Modernization and industrialization of the fishery since the 1950s has led to both rapid exploitation of newly discovered beds and increased illegal fishing, with widespread changes in the integrity of Corallium populations now documented throughout much of the Mediterranean (GFCM 1984, 1988, Santangelo et al. 1993, Galasso 2000, Linares et al. 2003). Large, highly branched C. rubrum colonies

Table 3. Corallium rubrum. Estimated reproductive output of 5 types of populations. Data for Calafuria populations are from Santangelo et al. (1993, 2003). Size structure data for other areas were modified from Garrabou et al. (2001), Tsounis et al. (2007) and Rossi et al. (2008) and are presented as the percentage of the population in each size class (height). For Costa Brava and Medas Island populations, $60 \%$ of polyps from colonies 2 to $4 \mathrm{~cm}$ height and $100 \%$ of polyps in larger corals were assumed to be fertile (Tsounis 2005). Totals for each area include the number of planula produced and the number expected to settle (in parentheses) assuming $95 \%$ mortality of larvae. PA: protected area, pop.: population

\begin{tabular}{|c|c|c|c|c|c|c|c|c|c|c|c|}
\hline \multirow{2}{*}{$\begin{array}{l}\text { Diam. } \\
(\mathrm{mm})\end{array}$} & \multicolumn{2}{|c|}{ Calafuria (coast) } & \multirow{2}{*}{$\begin{array}{l}\text { Height } \\
(\mathrm{mm})\end{array}$} & \multicolumn{2}{|c|}{ Costa Brava (shallow) } & \multirow{2}{*}{\multicolumn{2}{|c|}{$\begin{array}{l}\text { Medas Island (PA) } \\
\% \text { pop. Output }\end{array}$}} & \multirow{2}{*}{\multicolumn{2}{|c|}{$\begin{array}{l}\text { Deep } \longrightarrow \text { pop. Output } \\
\% \text { pos }\end{array}$}} & \multicolumn{2}{|c|}{ —Historic - } \\
\hline & No. & Output & & No. & Output & & & & & No. & Output \\
\hline$<0.6$ & 822 & 0 & 1 & & 0 & & 0 & & 0 & & 0 \\
\hline $0.6-1.2$ & 731 & 0 & 2 & 2 & 84 & 5 & 209 & 1 & 42 & & 0 \\
\hline $1.3-1.8$ & 463 & 926 & 3 & 5 & 418 & 19 & 1670 & 5 & 418 & & 0 \\
\hline $1.9-2.5$ & 323 & 3230 & 4 & 9 & 2506 & 25 & 9187 & 10 & 2784 & 3 & 835 \\
\hline $2.5-3.1$ & 167 & 3607 & 5 & 12 & 5011 & 20 & 11692 & 17 & 7099 & 5 & 2088 \\
\hline $3.2-3.7$ & 73 & 2847 & 6 & 10 & 5568 & 15 & 9465 & 18 & 10022 & 7 & 3898 \\
\hline $3.8-4.3$ & 21 & 1184 & 7 & 12 & 10440 & 8 & 7830 & 17 & 14790 & 10 & 8700 \\
\hline $4.4-4.9$ & 12 & 793 & 8 & 15 & 20880 & 4 & 21054 & 13 & 18096 & 10 & 13920 \\
\hline $5.0-6.2$ & 4 & 412 & 9 & 11 & 21054 & 2 & 4705 & 8 & 15312 & 14 & 26796 \\
\hline $6.3-6.8$ & 3 & 396 & 10 & 8 & 20880 & 2 & & 6 & 15660 & 16 & 41760 \\
\hline $6.9-7.4$ & 3 & 485 & 12 & 8 & 28954 & 1 & & 7 & 25334 & 13 & 47050 \\
\hline $7.4-8.0$ & 1 & 202 & 15 & 5 & 24870 & & & 1 & 4974 & 10 & 49740 \\
\hline \multirow[t]{3}{*}{$>8$} & 1 & 243 & 20 & 3 & 21222 & & & & 707 & 7 & 49518 \\
\hline & & & 30 & & & & & & & & 33825 \\
\hline & & & 50 & & & & & & & 1 & 19895 \\
\hline Total & \multicolumn{2}{|l|}{$\begin{array}{c}14325 \\
(725)\end{array}$} & & \multicolumn{2}{|c|}{$\begin{array}{l}50655 \\
(2500)\end{array}$} & \multicolumn{2}{|c|}{$\begin{array}{c}115238 \\
(5761)\end{array}$} & \multicolumn{2}{|c|}{$\begin{array}{c}161885 \\
(8094)\end{array}$} & \multicolumn{2}{|c|}{$\begin{array}{l}298024 \\
(14900)\end{array}$} \\
\hline
\end{tabular}


20 to $50 \mathrm{~cm}$ in height formerly played a paramount role in structuring the coralligenous zone through their trophic activity and biogenic structure. These functions have been lost as most populations in the Mediterranean are dominated by 2 to $5 \mathrm{~cm}$ tall colonies (Cicogna \& Cattaneo-Vietti 1993, Garrabou \& Harmelin 2002, Tsounis et al. 2007, Santangelo et al. 2007). Landings data may be indicative of similar population declines for Pacific Corallium beds, but few biological data are available from these regions.

\section{Fisheries and landings}

Official FAO landings data from the last 40 yr illustrate the characteristic boom and bust cycle of coral fisheries with rapid increases in effort and landings shortly after a discovery of a new Corallium bed, followed by sharp declines a few years later once the bed is depleted (FAO 2008). This trend has repeated itself throughout the history of the fishery; although no new commercially viable beds have been discovered since 1990 and landings have remained at historically low levels (Grigg 1982, Carleton \& Philipson 1987, Grigg 1989, Santangelo et al. 1993). However, other factors can also trigger changes in landings. For instance, markets were flooded with low quality Midway deepsea coral in 1981-1982, which caused a dramatic drop in the price of Corallium, rending fishing economically unsustainable (Grigg 2002). Japan and China (Taiwan) are reported to have abandoned fisheries in the central Pacific due to high costs of harvesting coral in deep water and increased landings of low quality coral, but not due to a strong decline in abundance or biomass (Kosuge 2007). If abundant coral resources still remained off the Emperor Seamount Chain, landings should contain large, living old growth colonies rather than only low quality coral as reported by Kosuge (2007). Yet, even though taxa known only from the Emperor Seamounts still show up in FAO data (e.g. Corallium sp. nov.), production over the last 2 decades is $<1 \%$ of the yield in the 1980s (FAO 2008), suggesting the dramatic and permanent ( 15 to $20 \mathrm{yr}$ ) decline in landings is the result of the collapse of Corallium populations.

Landings data from the Mediterranean also illustrate a sharp reduction in annual yield of nearly $75 \%$ from 2 to 3 decades ago (Santangelo \& Abbiati 2001, FAO 2008). During the 1980s, at least 25 locations supported the harvest of Corallium rubrum (Fig. 1), while today the only known commercially viable beds are found along the African coast from Morocco to Tunisia, in the Bonifacio Strait off western Sardinia, Italy, and off Costa Brava and Mallorca, Spain (Tsounis et al. 2007). Also, in many of beds fished today, divers are progres- sively extracting coral from deeper water as shallow resources are depleted. Recent spikes in landings since 2004 may be partially attributed to the exploitation of new areas off Morocco, Algeria and Croatia and harvest in deeper water habitats, although increases are also due to the harvest of an increasing number of smaller-sized colonies (Tsounis et al. 2006a). FAO landings data are aggregated by weight and provide no indication of the size or age of individual colonies. However, early Corallium literature, anecdotal reports from fishermen and museum collections all indicate that colonies once grew to a much larger size. For example, off Costa Brava the average diameter in a professional harvest from 2005 to 2006 was $7.8 \mathrm{~mm}$, while colonies $<10 \mathrm{~mm}$ diameter were rarely collected there 2 decades ago (Tsounis, 2005, Rossi et al. 2008).

Dredges are known to have caused extensive habitat impacts to the coralligenous zone in the Mediterranean (Chessa \& Cudoni 1988), and are likely to have removed most of the largest colonies of Corallium from exposed (horizontal and gently sloping) substrates in deep water, as well as juvenile and undersized colonies. Coral dredges are also extremely inefficient, as only about $40 \%$ of the detached colonies are entangled and retrieved (Grigg 1984). Shifts to a SCUBA fishery in the 1950s allowed less destructive selective harvesting. Nevertheless, areas formerly excluded from dredging in shallow water were suddenly available for exploitation, including corals concentrated on vertical slopes, under overhangs, near cave entrances and in crevices where coral dredges cannot operate (Rossi et al. 2008). SCUBA fisheries also tend to operate in a 'pulse fishing' mode, with local patches being selectively eliminated, leaving only inaccessible and non-commercially sized individuals before another patch is located and eliminated (Caddy 1993). A recent trend in the manufacture of jewelry from reconstituted coral may increase pressure on remaining populations, as undersized corals $(<7 \mathrm{~mm})$ become more valuable and vulnerable to harvest (Rossi et al. 2008). SCUBA fishers, especially poachers, are also removing entire colonies with pieces of substrate attached to their bases, whereas trawls tended to break off colonies while leaving their bases attached (Linares et al. 2003). This practice allowed for regrowth of colonies from remaining polyps located around the base, while removal of the entire colony offers no potential for recovery (Rossi et al. 2008).

\section{Population structure}

Population demographics, including density, size and age, are indicators of the status of benthic organisms and their vulnerability to fisheries and other stres- 
sors. Corallium typically occurs at densities of $<1$ colony $\mathrm{m}^{-2}$, with the exception of shallow C. rubrum populations that are now dominated by recruits and small adult colonies, largely in response to overexploitation (Rossi et al. 2008). Because of the sessile nature of Corallium species, further reductions in density associated with the selective removal of the largest colonies in a coral bed may alter reproductive potential due to allele effects. Corallium populations are already fragmented and highly isolated as a result of limited larval dispersal and a high degree of self-seeding, and they exhibit density-dependent recruitment (Weinberg 1976, Grigg 1989, Abbiati et al. 1993, Costantini et al. 2007a,b). Remnant colonies within coral beds below minimum legal size of harvest may contribute to rebuilding of these depleted populations, only if these beds are protected from fishing, but this may take decades due to their slow growth and size-dependent reproductive output (Garrabou \& Harmelin 2002).

For a modular organism that characteristically forms highly complex, branched colonies, a shift from historic measures of 20 to $50 \mathrm{~cm}$ to $<5 \mathrm{~cm}$ in height is equivalent to a loss of 80 to $90 \%$ of the reproductive modules of individual colonies. Corallium rubrum can become sexually mature at a young age (2 to $3 \mathrm{~cm}$ height), although they don't achieve $100 \%$ fertility until about $6 \mathrm{~cm}$ (Santangelo et al. 2003, Torrents et al. 2005, Tsounis et al. 2006b). The spawning potential in gorgonians is known to increase exponentially with size, with larger arborescent colonies producing up to $98 \%$ of the recruits (Babcock 1991, Beiring \& Lasker 2000, Santangelo et al. 2003, Torrents et al. 2005). Populations of $C$. rubrum today are dominated by small (mean $=3 \mathrm{~cm}$ ) colonies with 1 or 2 branches capable of producing $10 \mathrm{~s}$ to 100 s of larvae annually, as compared to the 1000 s of larvae produced by colonies that are double or triple in size (Santangelo et al. 2003, 2007, Torrents et al. 2005, Tsounis et al. 2006b, Rossi et al. 2008). Given settlement rates estimated at no more than $5 \%$ of the total larval production (Santangelo et al. 2003) and continued removal of colonies shortly after they reach the legal minimum size of $7 \mathrm{~mm}$ diameter, a typical shallow population today that is targeted by fishermen is estimated to exhibit a reproductive output that is no more than 10 to $20 \%$ of that produced in the 1960 s.

\section{Management and conservation}

National approaches to manage Corallium fisheries have included bans on non-selective gear, minimum sizes, quotas and spatial closures. These measures should be reexamined and adjusted based on new information on the biology and population dynamics of Corallium (Caddy 1993, Tsounis et al. 2007). For exam- ple, existing no-take areas (protected areas) for $C$. rubrum are relatively small and it is unclear whether they are sited such that they would replenish fished areas, given the high degree of genetic structure, brooding reproductive mode and evidence that populations are self-seeding (Costantini et al. 2007a). In addition to the need for larger MPAs, additional areas in shallow water should be closed to fishing, especially where other stressors (e.g. climate change) are having compounding impacts (Cerrano et al. 2000, Bramanti et al. 2007). As one alternative to permanent spatial closures, Caddy (1993) recommended rotational harvest on a 20 to 30 yr cycle. Some rebuilding of populations may occur over this time period, provided that an adequate number of reproductively mature colonies remain to allow replenishment. However, the proposed time frame may be too short to allow full recovery of populations, as colonies in areas protected from fishing for 15 to 30 yrs are still less than half the reported historic size (Francour et al. 2001, Tsounis et al. 2006a).

In one of the earliest demographic studies of Corallium rubrum, García-Rodríguez \& Massó (1986b) documented the harvest of colonies that were 5 to $14 \mathrm{yr}$ of age, which they concluded was well below maximum sustainable yield (MSY). Based on demographic studies conducted off Costa Brava, Spain, Tsounis et al. (2007) estimated an MSY of 98 yr, whereas the current practice of harvesting colonies once they achieve a $7 \mathrm{~mm}$ basal diameter (11 yr old colonies) results in only $6 \%$ of the potential yield. New methods of aging indicate colony age was underestimated by a factor of 2 to 4 and growth rates are 2.6 to 4.5 times lower than previously thought (Marschal et al. 2004, Roark et al. 2006), which further supports a delay in harvest until colonies achieve a much larger size. For instance, Rossi \& Gili (2007) recommended a minimum size of at least $8.6 \mathrm{~mm}$ diameter and $10 \mathrm{~cm}$ height to allow development of third order branching patterns to ensure adequate reproductive output to compensate for fishing pressure.

Over the last 3 decades, more conservative management actions have been proposed at various Corallium consultation workshops held by FAO (GFCM 1984, 1988), yet few of the recommendations have been implemented. Global trends in Corallium landings over the last $45 \mathrm{yr}$, as well as changes in population demographics of Mediterranean C. rubrum populations, demonstrate that precious corals are heavily exploited resources and they have been overfished in most locations. New technologies to harvest (SCUBA using mixed gases, use of remotely operated vehicles to first identify harvest areas) and manufacture jewelry from reconstituted Corallium may further enhance pressure on these resources through expanded illegal 
fishing, continued take of undersized colonies and progressive expansion into deeper areas that may have formerly served as a refuge for the species. Without new conservation measures, these species may be on the verge of collapse.

China took an ambitious step to list 4 Pacific species of Corallium in CITES Appendix III in 2008, but the protective measures do not extend to other countries or all species. A CITES Appendix II listing provides a mechanism to regulate trade and also promote adoption of more conservative national or regional management measures. Through implementation of sustainable management guidelines, commercial trade would still be allowed, because exporting countries could demonstrate the established level of harvest and trade is not detrimental to the survival of the species (Wijnstekers 1988).

Long-term trends in landings from both the Pacific and Mediterranean and available data on population demographics of Mediterranean Corallium rubrum populations provide evidence that known commercial beds of Corallium have declined to less than 20 to $30 \%$ of their historic baseline, meeting the criteria required for a CITES Appendix II listing. However, questions remain regarding the conservation benefits of CITES for these species, and the ability to effectively implement a potential listing (Green \& Hendry 1999). First and foremost, CITES regulates trade in species, which may not be possible for Corallium because of difficulties in identification, especially of processed material (polished and dyed jewelry including powdered and reconstituted Corallium). Identification to family (Corallidae) or genus would be possible, mirroring the approach taken with the other listed corals including the precious black corals (antipatharians). Stockpiled resources harvested prior to a listing and fossil Corallium would be excluded from CITES requirements, but mechanisms to differentiate these from recently harvested material would need to be developed. Furthermore, there are large local markets and trade between neighboring European Union countries, which would not be regulated by CITES. In contrast, a listing could reduce illegal trade and fishing and promulgate stronger management and enforcement by giving both exporting and importing countries joint responsibility for conservation. A CITES listing requires annual monitoring and reporting of landings and trade, filling critical gaps in knowledge of harvest and trade levels. A listing would also promote research on the status and trends of Corallium populations and the impacts of fisheries, as well as the adoption of more conservative management approaches, all of which would be necessary for the issuance of export permits that meet nondetriment requirements of a CITES Appendix II listing. While several new administrative burdens would be associated with a CITES Appendix II listing for Corallium, these are not insurmountable, having been successfully resolved in other species that presented similar challenges including stony corals, antipatharians and seahorses.

Acknowledgements. Funding for an international conservation program for Corallium was provided by the NOAA Coral Reef Conservation Program, NOAA/NMFS Office of Habitat Conservation and NOAA Oceanic and Atmospheric Research. I am grateful to K. Puglise, T. Hourigan and G. Roberts for their input and editorial advice. The US Fish and Wildlife Service, Division of Law Enforcement, provided LEMIS data on Corallium imports, and the US Scientific and Management Authorities have continued to support a potential listing for Corallium within the Appendices of CITES. Comments from 4 anonymous reviewers greatly improved the manuscript. I am also indebted to several Pacific and Mediterranean Corallium scientists, including F. Parrish, G. Tsounis, S. Rossi and G. Santangelo, who shared their data and contributed to discussions presented in this paper.

\section{LITERATURE CITED}

Abbiati M, Buffoni B, Caforio G, DiCola G, Santangelo G (1992) Harvesting, predation and competition effects on a red coral population. Neth J Sea Res 30:219-228

Abbiati M, Santangelo G, Novelli S (1993) Genetic variation within and between two Tyrrhenian populations of the Mediterranean alcyonarian Corallium rubrum. Mar Ecol Prog Ser 95:245-250

Anonymous (2007) Proposal 21. Convention on International Trade in Endangered Species of Wild Fauna and Flora. Consideration of proposals for amendment of Appendices I and II. 14th Meeting of the Conference of Parties, Hague, Netherlands

Babcock RC (1991) Comparative demography of three species of scleractinian corals using age- and size-dependent classification. Ecol Monogr 61:225-244

Baco A, Shank TM (2005) Population genetic structure of the Hawaiian precious coral Corallium lauuense (Octocorallia: Coralliidae) using microsatellites. In: Freiwald A, Roberts JM (eds) Cold-water corals and ecosystems. Springer-Verlag, Berlin/Heidelberg, p 663-678

Bayer FM, Cairns SD (2003) A new genus of the scleraxonian family Coralliidae (Octocorallia: Gorgonacea). Proc Biol Soc Wash 116:222-228

Beiring EA, Lasker HR (2000) Egg production by colonies of a gorgonian coral. Mar Ecol Prog Ser 196:169-177

Bramanti L, Magagnini G, Maio LD, Santangelo G (2005) Recruitment, early survival and growth of the Mediterranean red coral Corallium rubrum (L. 1758), a 4-year study. J Exp Mar Biol Ecol 314:69-78

> Bramanti L, Rossi S, Tsounis G, Gili JM, Santangelo G (2007) Settlement and early survival of red coral on artificial substrates in different geographic areas: some clues for demography and restoration. Hydrobiologia 580:219-224

Caddy JF (1993) Background concepts for a rotating harvesting strategy with particular reference to the Mediterranean red coral, Corallium rubrum. Mar Fish Rev 55:10-18

Carleton CC, Philipson PW (1987) Report on a study of the marketing and processing of precious coral products in Taiwan, Japan, and Hawaii. FFA Report 87/13. South Pacific Forum Fisheries Agency, New Caledonia 
Cerrano C, Bavastrello G, Bianchi CN, Catteneo-Vietti R and others (2000) A catastrophic mass-mortality episode of gorgonians and other organisms in the Ligurian Sea (NW Mediterranean), summer 1999. Ecol Lett 3:284-293

Chessa LA, Cudoni S (1988) Red coral, Corallium rubrum (L.) fishing in the 'Bocche di Bonnifacio' (Northern Sardinia, Italy). FAO Fish Rep 413:113-123

Cicogna F, Cattaneo-Vietti R (1993) Red coral in the Mediterranean Sea: art, history and science. Ministerio delle Risorse Agricole, Alimentari e Forestali, Roma

Costantini F, Fauvelot C, Abbiati M (2007a) Fine-scale genetic structuring in Corallium rubrum: evidence of inbreeding and limited effective larval dispersal. Mar Ecol Prog Ser 340:109-119

Costantini F, Fauvelot C, Abbiati M (2007b) Genetic structuring of the temperate gorgonian coral (Corallium rubrum) across the western Mediterranean Sea revealed by microsatellites and nuclear sequences. Mol Ecol 16:5168-5182

FAO (2007) Report of the second FAO ad hoc expert advisory panel for the assessment of proposals to amend Appendices I and II of CITES concerning commerciallyexploited aquatic species. Rome, 26-30 March 2007. FAO Fish Rep 833

FAO (2008) FishStat Plus datasets. Total fishery production 1950-2006. Available at www.fao.org/fishery/statistics/ software/fishstat/en

Francour P, Harmelin JG, Pollard D, Sartoretto S (2001) A review of marine protected areas in the northwestern Mediterranean region: siting, usage, zonation and management. Aquat Conserv 11:155-188

Galasso M (2003) Pesca del Corallium rubrum in Sardegna nell'antichita attraverso l'indagine archeologica, cartografica e 1 rilevamenti in mare. L'Africa romana, Atti del XIV Convegno di Studi, 7-10 Dec 2000, Sassari Redazione Archaeogate 26-03-2003:1-7

García-Rodríguez M, Massó C (1986a) Estudio biométrico de poblaciones de coral rojo (Corallium rubrum L.) del litoral de Gerona (NE de España). Bol Inst Esp Oceanogr 3: $61-64$

García-Rodríguez M, Massó C (1986b) Modelo de explotación por buceo del coral rojo (Corallium rubrum L.) del Mediterráneo. Bol Inst Esp Oceanogr 3:75-82

Garrabou J, Harmelin JG (2002) A 20 -year study on life-history traits of a harvested long-lived temperate coral in the NW Mediterranean: insights into conservation and management needs. J Anim Ecol 71:966-978

Garrabou J, Perez T, Sartoretto S, Harmelin JG (2001) Mass mortality event in red coral Corallium rubrum populations in the Provence region (France, NW Mediterranean). Mar Ecol Prog Ser 217:263-272

GFCM (General Fisheries Commission for the Mediterranean) (1984) Technical consultation on red coral resources in the Western Mediterranean. FAO Fish Rep 306

GFCM (1988) Report of the second GCFM technical consultation on red coral in the Mediterranean. FAO Fish Rep 413

> Green EP, Hendry H (1999) Is CITES an effective tool for monitoring trade in corals? Coral Reefs 18:403-407

Grigg RW (1974) Distribution and abundance of precious corals in Hawaii. Proc 2nd Int Coral Reef Symp 2:233-240

Grigg R (1977) Hawaii's precious corals. Island Heritage Publishing, Honolulu, HI

Grigg R (1982) Economics and future development of the precious coral fishery in the Pacific. Infofish 2:8-11

- Grigg R (1984) Resource management of precious corals: a review and application to shallow water reef building corals. PSZN I: Mar Ecol 5:57-74

Grigg RW (1989) Precious coral fisheries of the Pacific and
Mediterranean. In: Caddy JF (ed) Marine invertebrate fisheries: their assessment and management. John Wiley \& Sons, New York, p 637-645

Grigg RW (1993) Precious coral fisheries of Hawaii and the US Pacific Islands. Mar Fish Rev 55:50-60

Grigg RW (2001) Black coral: history of a sustainable fishery in Hawaii. Pac Sci 55:291-299

Grigg RW (2002) Precious corals in Hawaii: discovery of a new bed and revised management measures for existing beds. Mar Fish Rev 64:13-20

Grigg RW (2006) History of the black coral fishery in Hawaii 2006. In: Western Pacific Regional Fishery Management Council (ed) 2006 Black Coral Science and Management Workshop. 18-19 Apr 2006, Honolulu, HI, p 9-10

Kosuge S (1993) History of the precious coral fisheries in Japan. Precious Corals Octocoral Res 1:30-38

Kosuge S (2007) Situation about deep sea coral fisheries in the central Pacific. Bull Inst Malacol 3:1-7

Linares C, Diaz D, Hereu B, Zabala M (2003) Avaluació de ala poblacio de corall Corallium rubrum de les illes Medes. Exercici 2003. Seguiment temporal de l'area marina protegida de les illes medes. Infomre annual. Any 2003. Departament de Medi Ambient, Generalitat de Catalunya, Barcelona, p 56-66

Marschal C, Garrabou J, Harmelin JG, Pichon M (2004) A new method for measuring growth and age in precious red coral Corallium rubrum (L.). Coral Reefs 23:423-432

Mayol J (2000) Homo Delphinus: the dolphin within man. Idelson-Gnocchi, Reddick, NY

Morell V (2007) Corals: suffering from whiplash. Science 316: 1678

Roark EB, Guilderson TP, Dunbar RB, Ingram BL (2006) Radiocarbon-based ages and growth rates of Hawaiian deep-sea corals. Mar Ecol Prog Ser 327:1-14

Rossi S, Gili JM (2007) Assessment of red coral (Corallium rubrum) in GSA 06 (Northern Spain). General Fisheries Commission for the Mediterranean. Scientific Advisory Committee. Report of the ninth session of the sub-committee on stock assessment. Document 11, FAO, Rome

Rossi S, Tsounis G, Padrón T, Orejas C and others (2008) Survey of deep-dwelling red coral (Corallium rubrum) populations at Cap de Creus (NW Mediterranean). Mar Biol 154:533-545

Santangelo G, Abbiati M (2001) Red coral: conservation and management of an over-exploited Mediterranean species. Aquat Conserv 11:253-259

Santangelo G, Abbiati M, Giannini F, Cicogna F (1993) Red coral fishing trends in the western Mediterranean Sea during the period 1981-1991. Sci Mar 57:139-143

Santangelo G, Carlietti E, Maggi E, Bramanti L (2003) Reproduction and population sexual structure of the overexploited Mediterranean red coral Corallium rubrum. Mar Ecol Prog Ser 248:99-108

Santangelo G, Maggi E, Bramanti L, Bongiorni L (2004) Conservation biology and population demography of a Mediterranean overexploited species. Sci Mar 67:199-204

> Santangelo G, Bramanti L, Iannelli M (2007) Population dynamics and conservation biology of the overexploited Mediterranean red coral. J Theor Biol 244:416-423

Tescione G (1965) II corallo nella storia e nell'arte. Montanino Editore, Napoli $\mathrm{p}$

Tescione G (1973) The Italians and their coral fishing. Fausto Fiorentino, Napoli

Torrents O, Garrabou J, Marschal C, Hamelin JG (2005) Age and size at first reproduction in the commercially exploited red coral Corallium rubrum (L.) in the Marseilles area (France, NW Mediterranean). Biol Conserv 121:391-397 
Tsounis G (2005) Demography, reproductive biology and trophic ecology of red coral (Corallium rubrum L.) at the Costa Brava (NW Mediterranean): ecological data as a tool for management. Ber Polar-Meeresforsch 512

Tsounis G, Rossi S, Gili JM, Arntz W (2006a) Population structure of an exploited benthic cnidarian: the case study of red coral (Corallium rubrum L.). Mar Biol 149: 1059-1070

Tsounis G, Rossi S, Gili JM, Arntz W (2006b) Effects of spatial variability and colony size on the reproductive output and gonadal development cycle of the Mediterranean red coral (Corallium rubrum L.). Mar Biol 148:513-527

Submitted: February 24, 2009; Accepted: May 15, 2009
Tsounis G, Rossi S, Gili JM, Arntz W (2007) Red coral fishery at the Costa Brava (NW Mediterranean): case study for an overharvested precious coral. Ecosystems 10:975-986

US Dept of Commerce (1980) FMP for the precious coral fishery of the Western Pacific region. Fed Reg 45(180): 60957-60981

Weinberg S (1976) Revision of the common Octocorallia of the Mediterranean circalittoral. I. Gorgonacea. Beaufortia 24: 63-104

Wijnstekers W (1988) The evolution of CITES. Secretariat of the Convention on International Trade in Endangered Species of Wild Fauna and Flora, Lausanne

Proofs received from author(s): August 30, 2009 